\title{
Host-parasite translocation: A potential source of zoonoses emergence in Nigeria
}

\section{Temitope Emmanuel Arotolu ${ }^{1}{ }^{2}$ Ayodele Olaolu Oladejo ${ }^{3}$ and Ayodeji Moses Arojo ${ }^{4}$}

\author{
${ }^{1}$ Northeast Forestry University. Center of Conservation Medicine \& Ecological \\ Safety. Harbin 150040. Heilongjiang Province. China. Email: \\ temitopearotolu@yahoo.com. \\ ${ }^{2}$ Northeast Forestry University. College of Wildlife Resource. Harbin 150040, \\ Heilongjiang Province. China. \\ ${ }^{3}$ Oyo State college of Agriculture and Technology. Department of Animal Health \\ Technology. Igboora, Nigeria. \\ ${ }^{4}$ Federal University of Technology Akure. Department of Biology, School of Science. \\ Applied Parasitology Unit. Nigeria.
}

\begin{abstract}
Zoonoses are infectious diseases that are spread between animals and people. These diseases are transmitted to humans in many ways, such as direct contacts, indirect contacts, vector-borne, foodborne, and inhalation. Translocation and introduction of animals to new geographic regions correspond to increased human global travel and commerce as underlying factors for infectious disease emergence. In this review, we examined some potential notable driving mechanism of zoonosis in Nigeria. The population explodes, and demand for animal products has resulted in the expansion of animal trade, both local and international, animal and human movements, and intensification of livestock production systems. The above mentioned have an indirect role in zoonotic disease distribution. Animal husbandry, wildlife hunting, and hunting with dogs are potential routes of parasite translocation, most notably when infected animals are killed. Zoonotic diseases cause severe economic loss in the pathogenic spoilage of milk, contaminated animal products, carcass quality, weight loss, infertility, and loss of animal population. The cost of disease control decreases in household income due to a reduction in livestock/product sales. Also, consumption impacts due to reduced food availability, increased household vulnerability where livestock is used as a risk-coping mechanism, and effects on household finance, which influences household savings. Our suggestions for future effective zoonoses control include, an improved surveillance system, well-structured quarantine services, institutionalized one health approach, public enlightenment, interdisciplinary research, and ultimately a strict conservation rules and regulation may be turned into law to avoid transmission of Zoonosis through the consumption of wild animal which is most reservoir of causative pathogen.
\end{abstract}

Received

November 15, 2019

Accepted

August 30, 2020

Released

December 31, 2020

Full Text Article

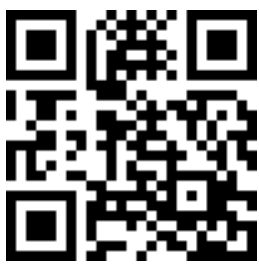

ORCID

(D) 0000-0003-1330-0160

Temitope Emmanuel Arotolu

(C) $0000-0002-0617-6619$

Ayodele Olaolu Oladejo

D 0000-0002-7112-4305 Ayodeji Moses Arojo 
Keywords: Zoonoses; Livestock; Wildlife; Parasite translocation; Wildlife hunting; Economic loss; Nigeria.

List of abbreviations:

ASR - Average spatial resolution

FAO - Food and Agricultural Organization

NGO - Non-Governmental Organizations

GDP - Gross Domestic Product

NASPHV - National Association of State Public Health

Veterinarians

NPAFS - National Programme for Agriculture and Food Security

\section{Introduction}

Zoonotic diseases account for about 75\% of emerging infectious diseases and can be devastating to both human and animal health globally. Zoonoses with a wildlife reservoir represent a broad spectrum of transmission modes. Many zoonotic agents can be directly transmitted from wildlife to humans (Kruse et al., 2004). Zoonotic diseases are infectious diseases caused by a variety of pathogenic agents, including bacteria, parasites, fungi, viruses, and prions that are naturally transmitted from vertebrate mammals to humans and vice versa (Wang and Crameri, 2014).

Zoonotic diseases are transmitted to humans in many ways such as direct contacts (animal bites, infected saliva, and scratches), inhalation (breathing in airborne spores or organisms), food animals, drinking unpasteurized dairy product, vectors like mosquitoes, tick, fleas, and lice's (Rojan Dahal, 2014; Olival et al., 2017). Indirect contacts with items in areas where animals live and roam or with objects or surfaces contaminated with germs. Most susceptible populations are people who have close contact with large numbers of animals such as farmers, hunters, abattoir or slaughterhouse workers, shearers, knackery workers, para veterinarians, veterinarians, and consumers who are therefore advised to take precautions (WHO, 1999; Belay et al., 2004).

Zoonotic agents can also be disseminated from wildlife to humans indirectly by contaminated food and water, for instance, Salmonella spp and Leptospiral spp. Zoonoses are also spread through insect vectors. For example, a mosquito is a well-known vector of rift valley fever, equine encephalitis, and Japanese encephalitis. Fleas can spread Y. pestes, Bacillus anthracis spores by flies and Leishmania by sand-flies, whereas, ticks are essential of Borrelia burgdorferi and Ehrlichia/Anaplasma.

Domestic carnivores (dogs and cats), livestock, or birds may also bring wildlife pathogens into closer proximity to humans (Spickler, 1955). Animals can be infected directly with the zoonotic agent, either clinically or sub-clinically, it may act as a transfer host for infected arthropods such as ticks. Non-traditional pets have a reasonably high probability of being infected with diseases causing organisms, particularly when captured from the wild. For example, during an outbreak of monkeypox in the United States of America, the virus spread from exotic African rodents (source infection), imported as pets, to pet prairie dogs, and then to humans (Mark and Buller, 2010). Agricultural activities such as hunting and fishing, bring people into closer contact with wildlife. These activities can result in exposure to organisms carried in wild animals (e.g., Francisella tularensis, Yersinia pestis, and Leptospira spp) or transmitted by arthropod vectors (e.g., Borrelia burgdorferi and West Nile virus). Hunters, in particular, may contact pathogens in animal tissues during butchering (Fiant et al., 2015).

The prevalence of other zoonotic diseases may be linked to cultural practices such as eating raw fish, gastropods, or mollusks. Knowledge of a person's leisure and vocational 
activities, travel, and pet ownership can sometimes raise the index of suspicion for zoonoses that are uncommon in urban populations (Spickler, 1955). Zoonoses may also result from an increased prevalence of the agent in domesticated or wild animals or vectors. Many currently emerging and reemerging diseases have reservoirs in wildlife and are foodborne (Spickler, 1955).

Translocation and introduction of animals to new geographic regions correspond to increased human global travel and commerce as underlying factors for infectious disease emergence (Hughes and Montagne, 1994; Greger, 2007). Animals, both livestock and wildlife, have long been identified as reservoir hosts of specific zoonotic pathogens. During migration, there is a high probability of infection risk with zoonotic pathogens. Conversely, an uninfected animal may be infected during translocation, most notably when they have contact with the migrating herd, which will invariably transmit to human. Eradicating zoonoses among wildlife population become unattainable, which is a significant concern and threat to conservation, diseases prevention, and control.

\section{The historical aspect of zoonoses in Nigeria}

Zoonoses have affected human health throughout times; a combination of climatic, ecological, agricultural, and socio-ecological factors has led to a hazardous situation in Nigeria. For example, rabies was first reported in Nigeria in 1912, and about 10,000 animal and human cases are published in the country, making the disease a persistent endemic problem (Ogunkoya et al., 2012). The rabies viral antigen has been detected in the brain tissue of apparently healthy dogs slaughtered for human consumption in almost all geopolitical zones of the country and poses a significant public health risk to dog meat processors and handlers (Hambolu et al., 2013). Rabies has also been diagnosed in bats, horses, monkeys, cats, and cows (NASPHV, 2007; NCDC, 2017).

Brucellosis is an endemic disease and has been reported sporadically from various areas of the country since 1927, mostly from established government herds. Fewer reports originated from nomadic and semi-nomadic herds, which comprise over 95\% of the livestock population managed mainly by the Fulani pastoralists (Ocholi et al., 1993). Lassa fever virus (LFV) was first described in 1969 from a case in the town of Lassa in Borno State, Nigeria. Lassa fever, an acute viral zoonotic illness caused by Lassa virus, an arenavirus known to be responsible for a severe hemorrhagic fever characterized by fever, muscle aches, sore throat, nausea, vomiting and, chest and abdominal pain.

The virus exhibits persistent, asymptomatic infection with excessive urinary virus excretion in the ubiquitous rodent vector, Mastomys natalensis. Lassa fever is endemic in Nigeria. Distribution of Confirmed Lassa Fever cases in Nigeria as at 28th April, 2019 reveals that Twenty-one (21) States (Edo, Ondo, Bauchi, Nasarawa, Ebonyi, Plateau, Taraba, FCT, Adamawa, Gombe, Kaduna, Kwara, Benue, Rivers, Kogi, Enugu, Imo, Delta, Oyo, Kebbi and Cross River) have recorded at least one confirmed case across 82 Local Government Areas (NCDC, 2019; Dan-Nwafor et al., 2019). In Nigeria, Mycobacterium tuberculosis is majorly considered to be the only cause of tuberculosis in humans (DanNwafor et al., 2019). As very little is known about zoonotic tuberculosis caused by M. bovis and other members of the M. tuberculosis complex (MTC), little attention is given to the reality that most Nigerians live in settings that enhance the transmission of zoonotic bovine tuberculosis (BTB) at the human-animal interface (Cadmus et al., 2004). Our preference for the diseases mentioned above was due to their occurrence in the country as reported on OIE (2019) and WHO Online databases.

\section{Status of livestock and economic importance of zoonoses in Nigeria}

Nigeria, the most populous country in Africa continent (http://esa.un.org/wpp/ASCII-Data/DISK_NAVIGATION_ASCII.htm), has an estimated 
livestock population of 19.09 million cattle, 37.44 million sheep, 65.65 million goats, 60.40 million pigs, and 101.5 horses (FAO, 2010; Table 1). Globally, Nigeria, India, Ethiopia, and Bangladesh account for $44 \%$ of poor livestock keepers with Nigeria ranking second (Grace et al., 2012). Livestock production has always been outstanding in Nigeria, and the rapidly emerging livestock sector now ranks first among the 20 poorest countries (Grace et al., 2012). With a vast pastoralist population, the livestock industry has been a significant focus of government attention since the colonial era. Approximately $70 \%$ of the population lives in rural areas, but there is now considerable rural-urban drift (Aregheore, 2009). An increase in demand for animal products has resulted in the expansion of animal trade, animal and human migrations, and intensification of livestock production systems. The geographic, economic, and social conditions across Nigeria determine the ruminant livestock production systems (Aregheore, 2009). An estimate suggests that, between 2010 and 2050 , beef, poultry meat, and milk consumption will increase by $117 \%, 253 \%$, and $577 \%$, respectively $(\mathrm{FAO}, 2018)$. As a consequence, the livestock sector will grow and transform, resulting in a new relationship between domestic animals, populations, natural resources, and wildlife (FAO, 2018).

Table 1. Country census data references.

\begin{tabular}{lcccc}
\hline Animal & ASR & Year & Census & FAOSTAT \\
\hline Sheep & 160.0 & 2011 & $37,440,022$ & $35,519,759$ \\
Goat & 158.7 & 2011 & $65,652,372$ & $56,524,075$ \\
Cattle & 163.0 & 2011 & $19.095,227$ & $16,577,962$ \\
Horse & 196.9 & 2005 & 101,509 & 101,509 \\
Pig & 153.9 & 2011 & $6,040,819$ & $7,471,730$ \\
\hline
\end{tabular}

Source: FAO global livestock distribution maps of 2010: extracted from the Gridded Livestock of the World (GLW, v. 3).

The livestock industry plays an essential role in the economy of Nigeria. It serves as a significant source of income and livelihood for the majority of Nigerians who are villagers and contributes about 5.2\% of the National Gross Domestic Product (GDP) (Karshima et al., 2018). Also, cattle, sheep, and goats contribute over $80 \%$ of the total meat produced in Nigeria (Ugwu, 2007; Adedipe, 2014). Despite these benefits, the outbreaks of well-known human diseases of zoonotic origin (either contracted through wildlife or livestock) in recent decades have caused economic losses at the national level.

Zoonotic diseases cause severe economic losses in Nigeria as a result of reductions in milk production, weight gain, fertility, and carcass quality (Solomon et al., 2018). Two studies investigate the monetary impact of Brucellosis in Nigeria. Magaji (1984) estimated the economic losses due to reduced fertility at 19.91 million USD and those due to reduced milk production at 124.5 million USD, amounting in total to $0.6 \%$ of the country's GDP. Esuruoso (1979) estimated the economic losses due to brucellosis for the Nigerian livestock industry at 218.57 million USD per annum, which is about 1.3 percent of the country's GDP. Expert elicitation data generates an estimated monetary loss due to brucellosis in cattle equals about $0.6 \%$ of the country's GDP, which is consistent with the available literature.

In addition to the negative impacts of Zoonosis on national human health and economy, zoonotic diseases also adversely affect animal health, jeopardize the diplomatic relations between countries and can undermine conservation efforts to protect the world's biodiversity (Karesh, et al., 2005; Olival et al., 2017). The index case of the 2014 
Ebola virus disease was a Liberian-American who flew from Liberia to Nigeria's most populous city of Lagos. In response, the Nigerian government increased surveillance at all entry points to the country (BBC, 2014). Airlines implemented bans on flights to and from the country. Also, zoonoses outbreaks will, in turn, leads to a fear of association with others and reduces labor force participation, closes places of employment, disrupts transportation, and motivates some government and private decision-makers to close seaports and airports. The negative impacts of zoonotic diseases on livestock productivity remain a significant challenge in the livestock industry globally (Wilson, 2011) despite the projected increased dependence on agriculture in the nearest future (Herrero and Thornton, 2013). Economic impacts of zoonoses exist beyond the cost of control, but also, decreases household income due to scale down in livestock/product sales, consumption impacts due to reduced food availability, increased household susceptibility where livestock is used as a risk-coping mechanism and effects on household finance which influences savings and gender equality (Birol et al., 2010).

\section{Host-parasite translocation routes}

Traditional or cultural attitude and practices of Nigerians which promotes zoonotic diseases emergence are highlighted below (Figure 1).

\section{Wildlife \\ Translocation}

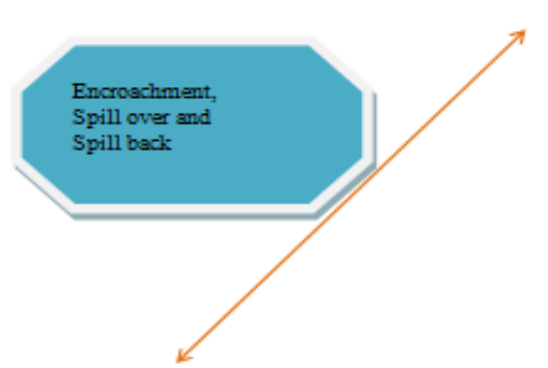

Livestock/Domestic animals

$$
\begin{gathered}
\text { (Extensive system of } \\
\text { animal Husbandry, } \\
\text { Pastoralism and, } \\
\text { Agricultural } \\
\text { intensification) }
\end{gathered}
$$

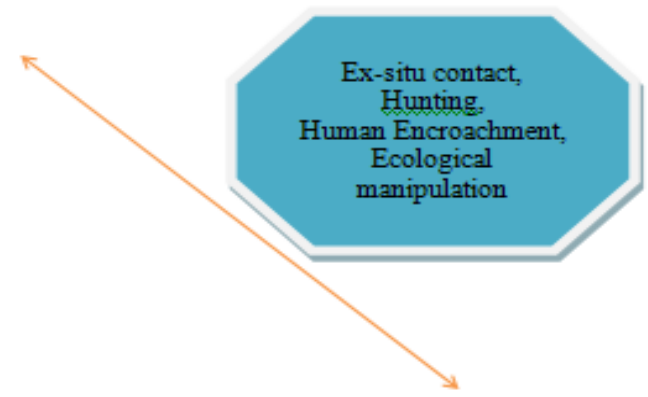

Human

(Urbanization,

Tourism, socio-cultural practices,

Global travel, and Biomedical manipulation)

Figure 1. Factors driving diseases emergence in wildlife, livestock and Human (Daszak et al., 2000). 


\section{Wild meat hunting and hunting with dog}

Wild meats are meats from non-domesticated vertebrate species (mammals, reptiles, amphibians, and birds) hunted for food in tropical forests. These wild animals exist in all ecosystems, including deserts, forests, plains, and grasslands (Ijeomah, et al., 2012). They are also called bush meat or game meat. Wild meat hunting threatens biodiversity and increases the risk of disease transmission from animals to people. However, hunting is perceived as a vocation in certain parts of Nigeria, especially in rural communities, where it might be a traditional family occupation (Ajayi, 1979; Martin, 1983). The activity takes place both day and night throughout the year, and anything more substantial than $2 \mathrm{~kg}$ is considered fair game meat (NFNBR, 2001).

Poaching is inevitable as the hunter will easily have access to wild animals in captive. Frequent contact with wildlife through the bushmeat trade puts people at risk of infection with zoonotic pathogens. Pathogens transmissible to humans through bushmeat include simian immunodeficiency virus, human T-cell lymphotropic virus, simian foamy virus, monkeypox virus, Ebola and Marburg filoviruses, anthrax, herpes viruses, hepatitis viruses, paramyxoviruses and various parasites (Fiant et al., 2015). Among prey bats, rodents and primates consistently stand out as essential sources of zoonoses. Bats and rodents have high zoonotic viral richness, and the close genetic similarity between humans and non-human primates makes exposure particularly risky (Davies and Pedersen, 2008; Meerburg et al., 2009; Pedersen \& Davies, 2009; Luis et al., 2012). For example, Forest-dwelling and peri-domestic rodents in West Africa host viruses such as the Lassa virus and monkeypox virus, as well as a range of vector-borne pathogens (Meerburg et al., 2009). Bats harbor the highest number of zoonotic viruses per host species and have received a great deal of recently because of outbreaks of zoonotic corona-, flo-, and paramyxoviruses (Chomel et al., 2007; Plowright et al., 2014). The repeated human interaction with these and other wildlife taxa determines the routes of zoonotic disease emergence.

Hunters in Nigeria are accustomed to the use of dogs as a companion in hunting, except for those who have religion bias having a dog around them. This practice is predominantly found among the hunters in rural communities, and they do have several trained dogs to assist them in hunting. The dog engages in a hot chase of wildlife, which sometimes leads to fighting, which draws the attention of the hunter to the scene. On some occasions, some untrained or callous dogs tend to prey on small rodents without the hunter's consent. During these activities, dogs have close contact with the animal even without knowing the animal health status; such a dog would still find its way to the hunter's family apartment which becomes more terrible among the illiterate and impoverished hunters who do not know about zoonotic diseases and could not afford vaccination from the veterinary hospitals.

Nigerians have a strong preference for bushmeat over domestic meat, which could be a result of cultural influence. This singular act has made the hunters go far into the thicket, and protected areas hunting to meet the demand from rural and urban markets continue to provide incentives through which they meet the need of their family, who often lack alternative ways to generate income (Fiant et al., 2015).

\section{Pastoralism}

The majority of Nigerians are dependent on livestock for their livelihood. This means of livelihood allows close interactions of humans with their animals and even wild animals due to the nomadic (migratory) nature of the pastoralists and farmers. This animal husbandry system has a potential exchange of infection between men and animals, some of which belong to the neglected category. It is estimated that about $30 \%$ of the Nigerian pastoralists are fully settled or sedentarised, 50\% are semi-nomadic, and only about $20 \%$ are genuinely nomadic. The semi-nomadic group sends their herd to the area 
of greener pasture during the dry season and return during the set season. On the other hand, the nomadic groups are continuously on the move according to the state of the pastorage or food supply. They have no fixed address (Grace et al., 2012; Abdullahi et al., 2015).

The above estimation reveals that both semi-nomadic and nomadic activities can lead to a zoonotic disease outbreak. During their seasonal and periodic migration, arguably, the herd establishes close contact with the wildlife and other domesticated animals, which may pose a severe health threat to humans, wildlife, and livestock through spillover and spillback. Pastoralists face a potential double burden of animals and human diseases as they fend for their livelihoods. Their daily activities (herding) puts them in close contact with their livestock and wildlife and, therefore, at high transmission risk (Bengis and Kock, 2002; Shirima et al., 2003; Kock, 2005; Ameni, 2013).

Other sources of infection associated with pastoralism which emanate through cultural practices are; consumption of raw or undercooked meat, drinking raw dairy milk, and other zoonotic diseases emergence risky behaviors (Spickler, 1955).

Herders during migration have no potable water; as such, they bath at the nearest stream and also sharing such water source with their livestock (Kambarage et al., 2003; Mazet, 2009). The ecological integrity or safety of the water body has not been proved safe for both livestock and human consumption. The upstream activities of such a water body are unknown; carcasses of infected animals might have washed down into the stream by erosion, thereby increasing the risk potential of the water body.

\section{Extensive system of animal husbandry}

This system of rearing animals is predominantly prevalent in Southern Nigeria, whereby the animals are not fended or cared for; they roam aimlessly for survival (Ezeibe, 2010). This system is often referred to as the free-range system. In 2001, Nigerian livestock farmers were rearing about 15.6 million poultry birds. Other animals also raised include 1 million horses, camels, and donkeys (PCOL, 2003). Also, in 2009, the Agricultural production survey (APS) conducted by the federal ministry of Agriculture and rural development shows that the stock of cattle, goat, sheep, and domestic fowls in Abuja (FCT) were 263,360; 3,009, 889; 958,443 and 7,406,408 respectively (NPAFS, 2010). The above estimates livestock reared under intensive, semi-intensive, and extensive systems in Abuja. Although the information on livestock in each category could not be accessed, the documented reported that the most common system among the small-scale farmers in Nigeria is the extensive system (Wilson, 1995; Nwese et al., 2003; Ovwigho et al., 2009; Ezeibe, 2010).

The activities of free-range animals are not monitored; as such, their risky behavior cannot be measured, some which would lead to the advent of zoonotic diseases. We highlighted below some risky behavior that is associated with free-range animals viz, proximity with wildlife during the search for food, mountain climbing, evading and wandering in the nature reserves and protected areas, movement into the wetlands for drinking, cooling off the body and relaxation in wetland areas. Man has purposefully allowed domestic pigs (Sus scrofa domesticus) mated with wild boars (Sus scrofa ferus) for more piglets, qualitative meats, low-cost maintenance (Matiuti et al., 2010) or for more distinct piglets having multi-skin coloration. The outcome of this singular act could birth the emergence of African swine fever, a highly resistant virus, and a potentially devastating disease.

Other predisposition factors are lack of potable water for rural households and communities, which make them dependent on the same water source with the livestock. Also, are agricultural activities such as irrigation and non-wearing of protective wears during farming operations could lead to the emergence of zoonotic diseases. 


\section{Conclusion}

Zoonotic diseases are not well reported in Nigeria, especially among the rural communities with few or no veterinarian or medico who could notify the authority about the disease occurrence. Therefore, there is urgent for the government to employ more veterinarians and para- veterinarians as stipulated in OIE Codex 2019. Also, some culture still believes certain zoonotic diseases and its symptoms as a consequence or aftermath of an angry god (e.g., monkeypox), some even consider it as a response from bewitchment by enemies. Through the joint efforts of the medical officials and the veterinarians, zoonotic diseases had been fought to a reasonable extent in livestock and human, however, if man will continue to go hunting, livestock seasonal migration and practice of free-range animal husbandry and other predisposing activities, there would be re-infection (spill-back) which will invariably frustrate the effort of the medical practitioners, these were one of the principal aims of One-health concept. Although prevention and control strategies for zoonotic diseases in wildlife, livestock, and humans share many common aspects. However, specific strategies are also needed to address the etiology and epidemiology of the disease, characteristics of the pathogen involved, disease ecology, and the population under threat.

A crucial part of managing the spread of the disease is the establishment of a proper surveillance system that will help develop countermeasures to prevent and control the disease. Meanwhile, to strengthen the efficiency of the early warning systems, monitoring trends, and disease prediction, and timely outbreak intervention, therefore, it is essential that Nigeria, as a nation, should improve its capacity in disease recognition and laboratory competence. We suggest a holistic one - human - Environmental - Animal health approach whereby environmentalist, wildlife conservationist, veterinarian, medico, epidemiologist and social scientists would collectively focus on human, animal (Pets, wildlife and livestock), and environment to improve public health and animal health through a practical integrated research approach to zoonotic pathogen biology, ecology, and epidemiology (spatial distribution and active control measure) (Chen et al., 2016).

The interdisciplinary and integrated research approach is necessary for the rapid identification and effective management of outbreaks and the prevention of zoonoses. There is a need to reorganize the nation quarantine service in other to curb transboundary animal diseases. More intensive research effort is required to understand the epidemiology and pathogenesis of various zoonotic diseases better, to improve diagnostic methods, and to develop cost-effective vaccines and drugs; it needs for the government, NGOs to fund research in the area of zoonotic diseases eradication and control. Training and availability of state-of-the-art facilities would enable the personnel involved at the various stages to detect zoonoses easily and present them with a novel research idea to containing zoonoses.

Information, education, and communication are vital components of any prevention and control strategy. Public education through sensitization and enlightenment and behavioral change are also essential factors for successful prevention and intervention. The term "zoonoses" has not been well understood by a high number of people in rural areas, hence, rural populace should be sensitized through national, state and local media on several risky behaviors that could predispose them and their animals (pets and livestock) to zoonoses, specifically targeting hunters, herdsmen, and farmers. There is a need to enact or re-enact animal conservation activities for the establishment of National Conservation Centers in all the geopolitical zones of the country and employment of personnel to enforce the laws. Conservation laws that limit hunting, or prohibit hunting with dogs, can be implemented with the help of community head and local chiefs may be most effective in reducing game hunting pressure, such as in the case of effectively monopolizing hunting privileges to residents' groups. However, given the cultural and 
economic conditions of the wild meat trade, a total shift to alternative protein sources may be impossible at present but achievable through public re-orientation and availability of alternative protein sources that would gratify local taste preferences (e.g., raising desirable species in captivity). The government should provide an alternative job for hunters to make ends meet.

\section{Conflict of interest}

The authors declare that they have no conflict of interest.

\section{References}

Abdullahi, U. S.; Daneyel, H. N.; Aliyara, Y. H. Grazing reserves and pastoralism in Nigeria: A review. Vom Journal of Veterinary Science, v. 10, p. 137-142, 2015.

Adedipe, O. D.; Uwalaka, E. C.; Akinseye, V. O.; Adediran, O. A.; Cadmus, S. I. B. Gastrointestinal helminths in slaughtered cattle in Ibadan, South-Western Nigeria. Journal of Veterinary Medicine, v. 2014, Article ID 923561, 2014. https://doi.org/10.1155/ 2014/923561

Ajayi, S. S. The utilization of tropical forest wildlife: State of knowledge and research priorities. Proceedings of the 8th World Forestry Congress, Dakarta, Indonesia, 1979.

Ameni, G.; Tadesse, K.; Hailu, E.; Deresse, Y.; Medhin, G.; Aseffa, A.; et al. Transmission of Mycobacterium tuberculosis between farmers and cattle in Central Ethiopia. PLoS One, v. 8, no. 10, p. 1-10, 2013. https://doi.org/10.1016/j.tvjl.2010.05.005

Aregheore E. M. Country pasture/forage resource profiles. Rome: FAO, 2009. Available from: <http://www.fao.org/ag/agp/AGPC/doc/Counprof/PDF files/Nigeria.pdf>. Accessed on: May 19, 2019.

BBC. Nigeria 'on red alert' over Ebola death in Lagos. BBC, 2014. Available from: <https://www.bbc.com/news/world-africa-28498665>. Accessed on: May 19, 2019.

Belay, E. D.; Maddox, R. A.; Williams, E. S.; Miller, M. W.; Gambetti, P.; Schonberger, L. B. Chronic wasting disease and potential transmission to humans. Emerging Infectious Diseases, v. 10, no. 6, p. 977-984, 2004. https://doi.org/10.3201/eid1006.031082

Bengis, R. G.; Kock, R. A.; Fischer, J. Infectious animal diseases: The wildlife/livestock interface. Revue Scientifique et Technique, v. 21, no. 1, p. 53-65, 2002.

Birol, E.; Asare-Marfo, D.; Ayele, G.; Mensah-Bonsu, A.; Ndirangu, L.; Okpukpara, B.; Roy, D.; Yakhshilikov, Y. Investigating the role of poultry in livelihoods and the impact of HPAI on livelihoods outcomes in Africa: Evidence from Ethiopia, Ghana, Kenya and Nigeria. Proceedings of the Third Conference/AEASA 48th Conference, Cape Town, South Africa, 2010.

Cadmus, S. I. B. Bovine tuberculosis in Nigeria: Historical perspective, burden, risk factors, and challenges for its diagnosis and control. In: Dibaba, A. B.; Kriek, N. P. J.; Thoen, C. O. Tuberculosis in animals: An African perspective. Cham: Springer. 363-378, 2019. p. 363-378.

Chen, W.-J.; Lai, S.-J.; Yang, Y.; Liu, K.; Li, X.-L.; Yao, H.-W.; Li, Y.; Zhou, H.; Wang, L.-P.; Mu, D.; Yin, W.-W.; Fang, L.-Q.; Yu, H.-J.; Cao, W.-C. Mapping the distribution of anthrax in Mainland China, 2005-2013. PLoS Neglected Tropical Disease, v. 10, no. 4, e0004637, 2016. https://doi.org/10.1371/journal.pntd.0004637 
Chomel, B. B.; Belotto, A.; Meslin, F.-X. Wildlife, exotic pets, and emerging zoonoses. Emerging Infectous Disease, v. 13, no. 1, p.6-11, 2007. https://doi.org/10.3201/ eid1301.060480

Dahal, R. Zoonotic diseases and one health approach. Epidemiology: Open Access, v. 4, e115, 2014. https://doi.org/10.4172/2161-1165.1000e115

Dan-Nwafor, C. C.; Furuse, Y.; Ilori, E. A.; Ipadeola, O.; Akabike, K. O.; Ahumibe, A.; Ukponu, W.; Bakare, L.; Okwor, T. J.; Joseph, G.; Mba, N. G.; Akano, A.; Olayinka, A. T.; Okoli, I.; Okea, R. A.; Makava, F.; Ugbogulu, N.; Oladele, S.; Namara, G.; Muwanguzi, E. N.; Naidoo, D.; Mutbam, S. K.; Okudo, I.; Woldetsadik, S. F.; Lasuba, C. L. P.; Ihekweazu, C. Measures to control protracted large Lassa fever outbreak in Nigeria. European Communicable Disease Bulletin, v. 24, no. 20, 1900272, 2019. https://doi.org/10.2807/15607917.ES.2019.24.20.1900272

Daszak, P.; Cunningham, A. A.; Hyatt, A. D. Emerging infectious diseases of wildlife: Threats to biodiversity and human health. Science, v. 287, no. 5452, p. 443-449, 2000. https://doi.org/10.1126/science.287.5452.443

Davies, T. J.; Pedersen, A. B. Phylogeny and geography predict pathogen community similarity in wild primates and humans. Proceedings of the Royal Society B: Biological Sciences, v. 275, p. 1695-1701, 2008. https://doi.org/10.1098/rspb.0284

Esuruoso, G. O. Current status of brucellosis in Nigeria and a preliminary evaluation of the probable cost and benefit of a proposed brucellosis control programme for the country. Proceedings of the Second International Symposium on Veterinary Epidemiology and Economics. Canberra: Australian Government Publishing Service, p. 644-649, 1979. Available from: <http://www.sciquest.org.nz/node/61028>. Accessed in: Oct. 28, 2019.

Ezeibe, A. B. C. Profitability analysis of pig production under intensive management system in Nsukka Local Government Area of Enugu State, Nigeria. International Journal of Economic Development Research and Investment, v. 1, p. 48-54, 2010.

FAO - Food and Agricultural Organization. Country brief: Nigeria. Africa Sustainable Livestock 2050. Abuja, Nigeria: FAO, 2018. Available from: < http://www.fao.org/ 3/CA2146EN/ca2146en.pdf>. Accessed on: Oct. 28, 2019.

FAO - Food and Agricultural Organization. 2010. Available from: <http://www.fao.org/ livestock-systems/global-distributions/en/>. Accessed on: Oct. 28, 2019.

Friant, S.; Paige, S. B.; Goldberg, T. L. Drivers of bushmeat hunting and perceptions of zoonoses in Nigerian hunting communities. PLoS Neglected Tropical Diseases, v. 9, no. 5, e0003792, 2015. https://doi.org/10.1371/journal.pntd.0003792

Grace, D.; Mutua, F.; Ochungo, P.; Kruska, R.; Jones, K.; Brierley. L.; Lapar, L.; Said, M.; Herrero, M.; Phuc, P. M.; Thao, N. B.; Akuku, I.; Ogutu, F. Mapping of poverty and likely zoonoses hotspots. Nairobi, Kenya: ILRI, 2012. (Zoonoses Project 4; Report to the UK Department for International Development). Available from: <https://cgspace.cgiar.org/ handle/10568/21161>. Accessed on: May 19, 2019.

Greger, M. The human/animal interface: Emergence and resurgence of zoonotic infectious diseases. Critical Reviews in Microbiology, v. 33, no. 4, 243-299, 2007. https://doi.org/ 10.1080/10408410701647594

Hambolu, S.; Dzikwi A.; Kwaga P.; Kazeem H.; Umoh J.; Hambolu D. Rabies and dog bites cases in Lagos State Nigeria: A prevalence and retrospective studies (2006-2011). Global Journal of Health Science, v. 6, no. 1, p. 107-114, 2013. https://doi.org/10.5539/ gjhs.v6n1p107 
Herrero, M.; Thornton, P. K. Livestock and global change: Emerging issues for sustainable food systems. Proceedings of the National Academy of Sciences USA, v. 110, p. 2087820881, 2014. https://doi.org/10.1073/pnas,1321844111

Hughes, J. M.; La Montagne J. R. Emerging infectious diseases. Journal of Infectious Diseases, v. 170, p. 263-263, 1994. https://doi.org/10.1093/infdis/170.2.263

Ijeomah, H. M.; Augustine, U. O.; Damilola, O. Analysis of poaching activities in Kainji Lake National Park of Nigeria. Environment and Natural Resources Research, v. 3, no. 1, 2012. https://doi.org/10.5539/enrr.v3n1p51

Kambarage, D. M.; Karimuribo, E. D.; Kusiluka, L. J. M.; Mdegela, R. H.; Kazwala, R. R. Community public health education in Tanzania: Challenges, opportunities and the way forward. In: FAO - Food and Agricultural Organization. Expert consultation on community based Veterinary Public Health (VPH) Systems. Rome, FAO, 2003. v. 9.

Karesh, W. B.; Cook, R. A.; Bennett, E. L.; Newcomb, J. Wildlife trade and global disease emergence. Emerging Infectious Diseases, v. 11, p. 1000-1002, 2005. https://doi.org/ 10.3201/eid1107.050194

Karshima, S. N.; Maikai, B.-V.; Kwaga, J. K. P. Helminths of veterinary and zoonotic importance in Nigerian ruminants: A 46-year meta-analysis (1970-2016) of their prevalence and distribution. Infectious Diseases of Poverty, v. 7, Article number 52, 2018. https://doi.org/10.1186/s40249-018-0438-z

Kock R. A. What is this infamous "wildlife/livestock disease interface"? A review of current knowledge for the African Continent. In: Osofsky, S. A.; Cleaveland, S.; Karesh, W. B.; Kock, M. D.; Nyhus, P. J.; Starr, L.; Yang, A. Conservation and development interventions at the wildlife/livestock interface: Implications for wildlife, livestock and human health. Gland, Switzerland: IUCN, 2005. p. 1-13. Available from: <http://www.fao.org/3/ax6198e.html>. Accessed on: May 19, 2019.

Kruse, H.; Kirkemo, A. M; Handeland, K. Wildlife as source of zoonotic infections. Emerging Infectious Diseases, v. 10, no. 12, p. 2067-2072, 2004. https://doi.org/ 10.3201/eid1012.040707

Luis, A. D.; Hayman, D. T. S.; O’Shea, T. J.; Cryan, P. M.; Gilbert, A. T.; Pulliam, J. R. C.; Mills, J. N.; Timonin, M. E.; Willis, C. K. R.; Cunningham, A. A.; Fooks, A. R.; Rupprecht, C. E.; Wood, J. L. N.; Webb, C. T. A comparison of bats and rodents as reservoirs of zoonotic viruses: Are bats special? Proceedings of the Royal Society London B Biological Sciences, v. 280, 20122753, 2013. https://doi.org/10.1098/rspb.2012.2753

Magaji, M. Economic impact of bovine brucellosis in Nigeria. Edinburgh: University of Edinburgh, 1984. (M. Sc. Dissertation).

Mark, R.; Buller, L. Poxviruses. In: Cohen, J.; Opal, S. M.; Powderly, W. G. (Eds.). Infectious diseases. 3. ed. London: Content Repository Only, 2010. p. 1577-1582.

Martin, G. H. G. Bushmeat in Nigeria as a natural resource with environmental implications. Environmental Conservation, v. 10, p.125-132, 1983. http://doi.org/10.1017/ S0376892900012212

Matiuti, M.; Bogdan, A. T.; Crainiceanu, E.; Matiuti, C. Research regarding the hybrids resulted from the domestic pig and the wild boar. Scientific Papers: Animal Science and Biotechnologies, v. 43, n. 1, p. 188-191, 2010. 
Mazet, J. A. K.; Clifford, D. L.; Coppolillo, P. B.; Deolalikar, A. B.; Erickson, J. D.; Kazwala, R. R. A "one health" approach to address emerging zoonoses: The HALI Project in Tanzania. PLoS Medicine, v. 6, no. 12, e1000190, 2009. https://doi.org/10.1371/ journal.pmed.1000190

Meerburg, B. G., Singleton, G. R.; Kijlstra, A. Rodent-borne diseases and their risks for public health. Critical Reviews in Microbiology, v. 35, p. 221-270, 2009. https://doi.org/ 10.1080/10408410902989837

NASPHV - National Association of State Public Health Veterinarians. Compendium of animal rabies prevention and control. Little Rock: NASPHV, 2007.

Ngoepe, C. E.; Sabeta, C.; Nel, L. The spread of canine rabies into Free State Province of South Africa: A molecular epidemiological characterization. Virus Research, v 142, no. 1/2, p. 175-180, 2009. https://doi.org/10.1016/j.virusres.2009.02.012

NPAFS - National Programme for Agriculture and Food Security. Report of the 2009 agricultural production survey (APS). Abuja, Nigeria: NPAFS, 2010.

Nweze, B. O.; Otuma, M. O.; Ekwu, L. G.; Oga, G. U. E. O. Agropastoral system in humid tropics. A case study of rice muturu integrated farming practice in Ebonyi State. Proceedings of the 8th Annual Conference of Animal Science Association of Nigeria, Maiduguri, Nigeria, p. 139-149, 2003.

Ocholi, R. A Brucellosis in Nigeria: A review. Tropical Veterinarian, v. 11, p. 15-26, 1993.

Ogunkoya, A. B.; Audu, S. W.; Mshelbwala, P. P.; Atuman, Y. J.; Ehimiyein, A. M.; Osinubi, M. O. V.; Garba, A.; Abidoye, E. O.; Onoja, I. E. Problems of rabies in Nigeria: A review. Proceedings of the 1st International Conference on Rabies in West Africa (RIWA), Ibadan, Nigeria, 2012.

OIE - World Organisation for Animal Health. World animal health information database (WAHIS interface). 2019. Available from: <http://www.oie.int>. Accessed on: Jun. 10, 2019.

Olival, K. J.; Hosseini, P. R.; Zambrana-Torrelio, C.; Ross, N.; Bogich, T. L.; Daszak, P. Host and viral traits predict zoonotic spillover from mammals. Nature, v. 546, p. 646, 2017. https://doi.org/10.1038/nature22975

Ovwigho, B. O.; Mmereole, F. U. C.; Udeh, I.; Akporhuarho, P. O. Comparison of constraints to poultry producers in Delta State Nigeria. International Journal of Poultry Science., v. 8, p. 480-484, 2009. https://doi.org/10.3923/ijps.2009.480.484

PCOL - Presidential Committee on Livestock. Reports of the presidential committee on livestock. Abuja, Nigeria: PCOL, 2003.

Pedersen, A. B.; Davies, T. J. Cross-species pathogen transmission and disease emergence in Primates. EcoHealth, v. 6, p. 496-508, 2009. https://doi.org/10.1007/s10393-0100284-3

Plowright, R. K.; Eby, P.; Hudson, P. J.; Smith, P. J.; Westcott, D.; Bryden, W. L.; Middleton, D.; Reid, P. A.; McFarlane, R. A.; Martin, G.; Tabor, G. M.; Skerratt, L. F.; Anderson, D. L.; Crameri, G.; Quammen, D.; Jordan, D.; Freeman, P.; Wang, L.-F.; Epstein, J. H.; Marsh, G. A.; Kung, N. Y.; McCallum, H. Ecological dynamics of emerging bat virus spillover. Proceedings of the Royak Society B, Biological Sciences, v. 282, 2014-2124, 2015. https://doi.org/10.1098/ rspb.2014.2124 
Shirima, G. M.; Fitzpatrick, J.; Cleaveland, S.; Kambarage, D. M.; Kazwala, R.; Kunda, J.; French, N. P. Participatory survey on zoonotic diseases affecting livestock keeping communities in Tanzania. Journal of Animal and Veterinary Advances, v. 2, p. 253-258, 2003.

Spickler, A. R. Transmission of zoonoses between animals and people. Kenilworth: Merck, 1955.

Ugwu, D. S. The role of small ruminants in the household economy of Southeast zone of Nigeria. Research Journal of Applied Sciences, v. 2, no. 6, p. 726-732, 2007.

Wang, L. F.; Crameri, G. Emerging zoonotic viral diseases. Revue Scientifique et Technique, v. 33, no. 2, p. 569-581, 2014. https://doi.org/10.20506/rst.33.2.2311

WHO - World Health Organization. Infection control guidelines for transmissible spongiform encephalopathies. Geneva, Switzerland: WHO/CDS/CSR/APH, 1999.

Wilson, P. Decomposing variation in dairy profitability: The impact of output, inputs, prices, labour and management. The Journal of Agricultural Science, v. 149, p. 507-517, 2011. https://doi.org/10.1017/S0021859610001176

Wilson, R. T. The tropical agriculturalists. In: Coste, R.; Smith, A. J. (Eds.). Livestock production systems. London: Macmillan, 1995.

License information: This is an open-access article distributed under the terms of the Creative Commons Attribution License, which permits unrestricted use, distribution, and reproduction in any medium, provided the original work is properly cited. 